\title{
PENINGKATAN KEAKTIFAN MAHASISWA DALAM MATA KULIAH PEMBELAJARAN TEMATIK MELALUI PENGGUNAAN PENDEKATAN SAINTIFIK
}

\author{
Yeni Nuraeni \\ Universitas Muhammadiyah Tangerang \\ yeniyayang1973@gmail.com
}

\begin{abstract}
The purpose of this research is to improve students' activity through a scientific approach. This research was conducted in Muhammadyah Tangerang University began in March-May 2017, with the subject of the study 30 students of level II. This study uses a model of action research methods Kemmis and McTaggart consisting of four phases, namely, planning, action, observation, and reflection. Data collection techniques using field notes, documentation, and observation. At this stage of data analysis using qualitative analysis model of Miles \& Huberman that includes reduction for simplification of data, display using tables, graphs, and verification. The results showed that the thematic learning subject study using the scientific approach can enhance the activity of the students. Based on the observation of the activity of students in Thematic learning in pre-cycle shows that the activity of $60 \%$ in the poor category. In the first cycle began an increase that is no student who is in the category of less, $85 \%$ are in the category enough and $15 \%$ are in either category of the number of 30 students. While on the second cycle students' activity in learning better Thematic learning process is already generating an atmosphere that stimulates students to be active with the fact that of the 20 indicators were observed, 30\% are in the category enough and $70 \%$ in both categories. Lecture's use a scientific approach that attracts students to actively explore the knowledge, information, concepts studied in Thematic learning.
\end{abstract}

Keywords : Student Activity, Scientific Approach, Thematic Learning , And Action Research

\begin{abstract}
ABSTRAK
Penelitian ini bertujuan untuk meningkatkan keaktifan mahasiswa melalui pendekatan saintifik. Penelitian dilaksanakan di Universitas Muhammadyah Tangerang mulai bulan Maret - Mei 2017 dengan subjek penelitian 30 mahasiswa tahun ke II. Penelitian menggunakan metode penelitian tindakan model Kemmis dan McTaggart yang terdiri dari empat tahap yaitu, perencanaan, tindakan, observasi, dan refleksi.Teknik pengumpulan data menggunakan catatan lapangan, dokumentasi, dan observasi. Pada tahap analisis data menggunakan analisis kualitatif model Miles \& Huberman yang meliputi reduksi untuk penyederhanaan data, display dengan menggunakan tabel, grafik, dan verifikasi.Hasil penelitian menunjukkan bahwa matakuliah pembelajaran tematik dengan menggunakan pendekatan saintifik dapat meningkatkan keaktifan mahasiswa. Berdasarkan hasil observasi terhadap keaktifan mahasiswa dalam mata kuliah pembelajaran tematik pada pra siklus memperlihatkan bahwa keaktifan $60 \%$ dalam kategori kurang. Pada siklus I mulai terjadi peningkatan yaitu tidak ada mahasiswa yang berada pada kategori kurang, $85 \%$ berada pada kategori cukup dan 15\% berada pada kategori baik dari jumlah 30 mahasiswa. Sedangkan pada siklus II keaktifan
\end{abstract}


mahasiswa dalam mata kuliah pembelajaran tematik lebih baik proses pembelajaran sudah memunculkan suasana yang merangsang mahasiswa untuk aktif dengan kenyataan bahwa dari 20 indikator yang diobservasi, 30\% berada pada kategori cukup dan $70 \%$ pada kategori baik. Dosen menggunakan pendekatan saintifik yang menarik mahasiswa untuk aktif melakukan eksplorasi terhadap pengetahuan, informasi, konsep-konsep yang dipelajari dalam mata kuliah pembelajaran tematik.

Kata kunci : Keaktifan Siswa, Pendekatan Saintifik, Mata Kuliahpembelajaran Tematik, Dan Penelitian Tindakan.

\section{A. PENDAHULUAN}

Dilihat dari perkembangan karakteristik peserta didik Sekolah Dasar sangat beragam, mereka dalam tahap perkembangan usia 7 sampai dengan 12 tahun. Pada usia 7-12 umumnya senang bermain, bergerak, dan senang melakukan sesuatu secara langsung. Hal ini menuntut seorang pendidik untuk menggunakan pendekatan yang sesuai dengan kebutuhan dan perkembangan peserta didik, pengalaman dan karakter masingmasing. Pada lembaga Sekolah Dasar kegiatan peserta didik harus diarahkan pada pembentukan suatu kemampuan dan keterampilan serta dapat melakukannya dengan baik. Anak memperoleh berbagai pengalaman akademik yang dikembangkan melalui sekolah. Masa ini adalah masa dimana anak memasuki dunia nyata.
Peserta didik pada Sekolah Dasar yang duduk di kelas-kelas awal (kelas I, II \& III) berada dalam rentangan usia dini. Pada usia dini, seluruh aspek perkembangan kecerdasan anak (IQ, EQ dan SQ) tumbuh dan berkembang sangat luar biasa cepat sehingga usia ini sering disebut usia emas (golden age) dalam perkembangan anak. Dalam aspek perkembangan kognitif (berdasarkan teori/ tahap perkembangan kognitif Piaget), anak usia ini berada pada tahap transisi dari tahap pra operasi ke tahap operasi konkrit. Piaget, dalam hal ini menyatakan setiap anak memiliki cara tersendiri dalam menginterpretasikan dan beradaptasi dengan lingkungannya. Menurutnya, setiap anak memiliki struktur kognitif yang disebut schemata, yaitu sistem konsep yang ada dalam pikiran sebagai hasil pemahaman terhadap berbagai obyek yang ada dalam lingkungannya. Pemahaman tentang 
Pendas : Jurnal Ilmiah Pendidikan Dasar, ISSN Cetak : 2477-2143 ISSN Online : 2548-6950 Volume II Nomor 1, Juni 2017

obyek tersebut berlangsung melalui proses asimilasi ( menghubungkan obyek dengan konsep yang sudah ada dalam pikirannya) dan akomodasi (proses memanfaatkan konsep dalam pikiran untuk menafsirkan obyek). Proses belajar anak tidak sekedar menghafal konsep-konsep dan faktafakta, tetapi merupakan kegiatan menghubungkan konsep-konsep untuk menghasilkan pemahaman yang lebih utuh. Belajar dimaknai dengan proses interaksi dari anak dengan lingkungannya. Anak belajar dari hal-hal yang konkrit, yakni yang dapat dilihat, didengar, diraba dan dibaui. Hal ini sejalan dengan falsafah konstrukksivisme yang menyatakan bahwa manusia mengkonstruksi pengetahuannya melalui interaksi dengan konkrit, yakni yang dapat dilihat, didengar,diraba dan dibaui.

Hal ini sejalan dengan falsafah konstruksivisme yang menyatakan bahwa manusia mengkonstruksi pengetahuannya melalui interaksi dengan obyek, fenomena, pengalaman dan lingkungannya. Pengetahuan ini tidak dapat ditransfer begitu saja dari seorang pendidik kepada anak. Sejalan dengan tahap perkembangan dan karakteristik cara anak belajar tersebut, maka pendekatan pembelajaran peserta didik SD kelas-kelas awal adalah pembelajaran tematik, dan pada Kurikulum 2013 pendekatan ini digunakan untuk semua tingkatan kelas di Sekolah Dasar yaitu mulai kelas I sampai dengan kelas VI. Dapat disimpulkan beberapa alasan mengapa pembelajaran tematik sangat penting untuk anak usia Sekolah Dasar yaitu:

1. Proses belajar anak tidak sekedar menghafal konsep-konsep dan fakta-fakta

2. Pembelajaran anak merupakan kegiatan menghubungkan konsep-konsep untuk menghasilkan pemahaman yang lebih utuh.

3. Belajar dimaknai dengan proses interaksi dari anak dengan lingkungannya.

4. Anak belajar dari hal-hal yang konkrit,

5. Anak belajar dari apa yang dapat dilihat, didengar, diraba dan dibaui.

6. Anak belajar mengkonstruksi pengetahuannya melalui interaksi dengan hal yang konkrit,

7. Anak mengkonstruksi pengetahuannya melalui interaksi 
Pendas : Jurnal IImiah Pendidikan Dasar,

dengan obyek, fenomena, pengalaman dan lingkungannya.

8. Pengetahuan ini tidak dapat ditransfer begitu saja dari seorang pendidik kepada anak.

9. Pembelajaran tematik sejalan dengan tahap perkembangan dan karakteristik cara anak belajar

10. Anak harus berada dalam keadaan senang dan aktif dalam pembelajaran

11. Pembelajaran yang bersifat universal lebih memudahkan bagi anak daripada yang bersifat parsial atau terkotakkotak.Paparan di atas, menggambarkan bahwa calon guru SD wajib dibekali dengan kemampuan mengajar dengan pendekatan tematik, sehingga mata kuliah pembelajaran tematik perlu diperoleh oleh mahasiswa PGSD.

Berdasarkan observasi terhadap data hasil pre test, 65 persent mahasiswa belum memahami tentang pembelajaran tematik .Agar mahasiswa memiliki motivasi yang tinggi dan tertarik dengan mata kuliah pembelajaran tematik, maka dosen harus memilih sebuah pendekatan yang tepat agar mahasiswa dapat belajar dengan aktif dan menyenangkan.

Syarifudin, dkk. (2010:107) mengemukakan bahwa untuk mengetahui keaktifan siswa dalam proses pembelajaran dapat dilihat dari tolak ukur yaitu (1) partisipasi peserta didik, (2) penekanan pada aspek efektifitas dalam pengajaran, (3) interaksi antara siswa, penerimaan, (5) keeratan kelas sebagai kelompok, (6) kesempatan yang diberikan kepada peserta didik, (7) Jumlah waktu yang digunakan.

Keaktifan mahasiswa dalam proses pembelajaran akan menyebabkan interaksi yang tinggi antara guru dengan siswa ataupun dengan siswa itu sendiri, sehingga siswa dapat lebih mudah mencapai tujuan pembelajaran yang tetap diharapkan. Hal ini akan mengakibatkan suasana kelas menjadi segar dan kondusif, dimana masing-masing siswa dapat melibatkan kemampuannya semaksimal mungkin.

Proses membangun konsep
atau pengetahuan baru secara mandiri akan ditemukan apabila siswa memiliki keaktifan dalam belajar. Konsep atau pengetahuan yang ditemukan atau dibangun oleh siswa 
Pendas : Jurnal Ilmiah Pendidikan Dasar,

akan lebih lama diingat karena akan tersimpan dalam memori jangka panjang siswa. Bahwa keterlibatan siswa dalam pengalamanpengalaman yang bermakna sebagai inti dari pembelajaran. Perubahan ini dari pemberian informasi yang pasif kepada pemecahan masalah yang aktif.

Mahasiswa PGSD adalah para calon guru yang saat menjalani profesinya nanti akan berhadapan dengan peerta didik yang memiliki karkter unik. Hal ini menuntut calon guru SD memiliki bekal untuk mengembangkan kompetensi peserta didik sesuai dengan karakteristiknya. Karakteristik pada siswa SD adalah rasa ingin tahunya yang sangat tinggi, sehingga siswa perlu diberikan tantangan untuk dapat menjawab rasa keingin tahuannya. Siswa SD juga memiliki motivasi untuk mengerjakan tugas. Sangat penting bagi guru secara konsisten memotivasi agar anak dapat menguasai pengetahuan dari rasa ingin tahunya. Banyak tantangan dapat diberikan dalam tugas belajar namun jangan terlalu memberatkan, ciptakan kegiatan belajar yang akan membuat anak produktif dan kreatif. Anak-anak pada tahap ini juga mulai kritis terhadap perkembangan moral. Guru dapat membantu perkembangan sosial ini dengan menunjukkan keterbukaan, kekonsistenan, kesopanan, kebijaksanaan, aktif, kreatif dan tingkah laku lain yang tepat. Pemilihan pendekatan scientific sangat tepat bila dihubungkan dengan teori ini.

Pendekatan scientific dipilih oleh dosen sebagai salah satu pendekatan yang digunakan dalam pembelajaran tematik untuk meningkatkan keaktifan mahasiswa. Sani (2014) Pendekatan Scientific (IImiah) adalah "Melibatkan kegiatan pengamatan atau observasi yang dibutuhkan untuk perumusan hipotesis atau mengumpulkan data" (h. 50).Sedangkan menurut Daryanto (2014) pendekatan Scientific adalah proses pembelajaran yang dirancang sedemikian rupa agar peserta didik secara aktif mengkonstruksi konsep, hukum atau prinsip-prinsip melalui tahapan-tahapan mengamati (untuk mengidentifikasi atau menemukan masalah), merumuskan masalah, mengajukan atau merumuskan hipotesis, mengumpulkan data dengan berbagai teknik menganalisis data, menarik kesimpulan, dan mengomunikasikan konsep (h. 51). 
Pendas : Jurnal IImiah Pendidikan Dasar, ISSN Cetak : 2477-2143 ISSN Online : 2548-6950 Volume II Nomor 1, Juni 2017

\begin{abstract}
Maksud dari pengertian Daryanto tentang Pendekatan Scientific adalah proses pembelajaran yang sudah dirancang sedemikian rupa agar peserta didik mampu mengonstruk konsep yang sudah dirancang dengan menggunakan tahapan mengamati, menanya, mengumpulkan informasi, mengasosiasikan/mengolah informasi /menalar, menarik kesimpulan, dan mengomunikasikan.
\end{abstract}

Menurut penjelasan dari ahli diatas tentang Pendekatan Scientific, penulis dapat menyimpulkan bahwa Pendekatan Scientific adalah suatu suatu proses pembelajaran yang sudah dirancang agar peserta didik secara aktif dapat melalui tahapantahapan seperti mengamati, menanya, mengumpulkan informasi, mengasosiasikan/mengolah informasi/ menalar, menarik kesimpulan, mengomunikasikan. Dengan menggunakan Scientific Aproach diharapkan mahasiswa dapat dengan mudah memahami mata kuliah pembelajaran tematik dengan mudah dan aktif dalam mengikuti proses perkuliahannya.

Maksud dari pengertian tentang Pendekatan Scientific di atas adalah proses pembelajaran yang sudah dirancang sedemikian rupa agar peserta didik mampu mengonstruk konsep yang sudah dirancang dengan menggunakan tahapan mengamati, menanya, mengumpulkan informasi, mengasosiasikan/mengolah informasi/ menalar, menarik kesimpulan, dan mengomunikasikan. Penulis dapat menyimpulkan bahwa Pendekatan Scientific adalah suatu suatu proses pembelajaran yang sudah dirancang agar peserta didik secara aktif dapat melalui tahapan-tahapan seperti mengamati, menanya, mengumpulkan informasi, menalar, menarik kesimpulan, mengomunikasikan. Mahasiswa yang dituntut untuk memiliki kemandirian dalam belajar keaktifannya akan terangsang dengan menggunakan pendekatan scientific. Hasil penelitian Martin Cápay and Martin Magdin (2015) yang berjudul "Tasks for Teaching Scientific Approach Using the Black Box Method", yang mengemukakan bahwa: In our experience, applications functioning as black boxes were proved to be adequate "recovery" activities within longer lectures (university), as well as an example of playful learning activities. This concept can be used in teaching, or even in leisure activities, for the 
Pendas : Jurnal IImiah Pendidikan Dasar,

activation of students. The contribution of the Black Box Method lies in development of students' curiosity, systematic approach and critical thinking while gaining new knowledge.

Martin menyimpulkan bahwa dengan scientific ini dapat meningkatkan sikap kritis dan rasa ingin tahu peserta didik, merupakan sebuah pendekatan sistematis untuk mendapatkan informasi dalam menyelesaikan masalah serta memperoleh pengetahuan baru.

Dari uraian di atas terlihat perlu diadakan penelitian tentang adanya inovasi dalam penggunaan pendekatan pembelajaran scientific yang akan meningkatkan keaktifan mahasiswa dalam pembelajaran,terutama mata kuliah pembelajaran tematik , karena banyak mahasiswa yang belum memahami tentang ini, agar tujuan pembelajaran tercapai secara optimal.

\section{B. METODE PENELITIAN}

Penelitian ini menggunakan penelitian tindakan (Action Research). Desain tindakan/rancangan siklus dalam penelitian ini menggunakan Kemmis dan Mc. Taggart, dengan menggunakan sistem spiral yang dimulai (a) perencanaan (planning), (b) tindakan (acting); (c) observasi (observation); (d) refleksi (reflection)

Penelitian tindakan ini dilakukan melalui dua siklus, yang disesuaikan dengan kondisi dan hasil refleksi ketercapaian peningkatan yang diharapkan pada siklus sebelumnya, sesuai dengan tindakan yang dilakukan. Pada siklus pertama belum berhasil maka dilanjutkan pada siklus berikutnya. Penelitian tindakan dilakukan secara klasikal, peneliti tidak melakukan terhadap masalah perseorangan atau individu. Maka semua mahasiswa yang ada di dalam kelas dikenai perlakuan tindakan oleh peneliti. Dalam penelitian ini, peneliti mengambil metode sebagai tindakan perlakuan untuk memecahkan masalah belajar yaitu masalah sikap pasif mahasiswa dalam mata kuliah pembelajaran tematik.. Inti dalam penelitian tindakan adalah untuk meningkatkan mutu pembelajaran.

Masalah yang diangkat oleh peneliti adalah masalah yang dialami dan ditemukan di dalam kelas sehingga peneliti memerlukan sebuah hal baru untuk menyelesainya. Pendekatan scientific merupakan hal baru yang digunakan di dalam mata 
Pendas : Jurnal Ilmiah Pendidikan Dasar, ISSN Cetak : 2477-2143 ISSN Online : 2548-6950 Volume II Nomor 1, Juni 2017

kuliah pembelajaran tematik di tempat peneliti melakukan penelitian. Penelitian Tindakan memberikan upaya kritis peneliti terhadap objek penelitian, termasuk diri peneliti (dosen). Dalam Penelitian Tindakan dosen juga berperan sebagai praktisi, merupakan sebuah elemen bagian dari instrumen penelitian. Penelitian Tindakan diawali dengan suatu kajian terhadap permasalahan secara sistematis. Hasil kajian dijadikan suatu formula untuk mengatasi permasalahan tersebut. Dalam proses realisasi dari perencanaan, dilakukan suatu observasi dan evaluasi yang hasilnya digunakan sebagai materi refleksi atas apa yang terjadi di lapangan. Menurut Madya (2009) hasil dari refleksi kemudian menjadi landasan upaya perbaikan dan penyempurnaan rencana tindakan berikutnya. Tahapan-tahapan ini dilakukan berulang-ulang dan berkesinambungan atau dikenal dengan istilah siklus, sampai kualitas suatu tingkat keberhasilan tertentu/tujuan dapat terwujud (h58).

Pada tahap perencanaan tindakan yang meliputi perencanaan umum dan perencanaan khusus. Perencanaan umum meliputi perencanaan waktu pelaksanaan penelitian yang akan dilakukan selama kurang lebih dua bulan. Peneliti mengadakan pertemuan dengan pimpinan untuk konsultasi, dan pertemuan dengan dosen yang menjadi rekan sejawat peneliti untuk mendiskusikan langkah-langkah pelaksanaan penelitian. Selain itu direncanakan pengaturan kondisi kelas, persiapan materi perkuliahan serta media/alat pembelajaran yang diperlukan, pembuatan kisi-kisi instrumen observasi tindakan, dan kisi-kisi instrumen keaktifan mahasiswa.

Adapun perencanaan khusus disesuaikan dengan jadwal perkuliahan dan disusun dalam tiap pelaksanaan tindakan. Dalam hal ini peneliti membuat rencana perkuliahan sesuai Kurikulum yang berlaku yaitu kurikulum KKNI, menyiapkan media pembelajaran yang diperlukan pada setiap pelaksanaan tindakan, menyiapkan lembar observasi tindakan dan instrumen keaktifan mahasiswa, serta pengumpulan data lainnya berkaitan dengan penelitian ini. Tahapan pelaksanaan tindakan merupakan realisasi tindakan pada dasarnya disesuaikan dengan setting tindakan yang telah ditetapkan dalam RPS. Tindakan dilaksanakan sejalan 
Pendas : Jurnal IImiah Pendidikan Dasar, ISSN Cetak : 2477-2143 ISSN Online : 2548-6950 Volume II Nomor 1, Juni 2017

dengan langkah-langkah pendekatan scientific yang telah direncanakan, untuk meningkatkan keaktifan mahasiswa. Penelitian tindakan ini dilaksanakan dalam dua siklus, masing-masing siklus dilakukan 2 kali tindakan dengan alokasi waktu adalah $2 \times 50$ menit pertemuan 1 dan $2 \times 50$ menit pertemuan 2 sesuai dengan program pada RPS.

Instrumen pengumpulan data yang digunakan sebagai bahan penilaian terhadap keaktifan mahasiswa adalah menggunakan instrumen pengumpulan data yang telah dipersiapkan, seperti instrument keaktifan mahasiswa dan berupa lembar observasi/pengamatan ketika menjalankan pendekatan Scientific Kegiatan observasi (observing) dilakukan bersamaan dengan pelaksanaan tindakan yang bertujuan untuk mengenali, merekam dan mendokumentasikan proses pembelajaran yang terjadi, berkenaan dengan kegiatan dosen dan mahasiswa selama tindakan dilakukan. Observer mengamati pelaksanaan kegiatan perkuliahan dengan menggunakan lembar observasi aktivitas dosen dan mahasiswa, sambil merekam atau mendokumentasikannya. Hasil rekaman dan dokumentasi penting dilakukan agar data yang diperlukan dalam penelitian ini dapat dijaring secara lengkap dan akurat. Selain itu peneliti mencatat semua peristiwa atau hal yang terjadi di kelas selama proses perkuliahan berlangsung. Tahapan refleksi tindakan merupakan upaya mengkaji secara menyeluruh tindakan yang telah dilakukan, berdasarkan data yang telah terkumpul, kemudian melakukan evaluasi untuk menyempurnakan tindakan berikutnya. Tahapan ini yang dilakukan oleh peneliti dan kolaborator setelah pelaksanaan tindakan. Kegiatan refleksi dilakukan secara kolaboratif, dengan mendiskusikan hasil analisis lembar observasi, catatan lapangan, serta faktor penyebab permasalahan lainnya yang terjadi selama pembelajaran di kelas. Hasil refleksi ini menjadi acuan revisi untuk menentukan perencanaan kembali (replanning) pada siklus berikutnya.

Peneliti dan kolaborator mengevaluasi kekurangan atau kelemahan serta kemajuan-kemajuan yang diperoleh dosen dan mahasiswa. Selain itu dalam kegiatan refleksi, dilakukan perbandingan peningkatan keaktifan mahasiswa, 
Pendas : Jurnal IImiah Pendidikan Dasar, ISSN Cetak : 2477-2143 ISSN Online : 2548-6950 Volume II Nomor 1, Juni 2017

sebelum dan sesudah diberikan tindakan. Apabila belum terjadi peningkatan keaktifan mahasiswa, maka penelitian dilanjutkan pada siklus berikutnya. Setelah beberapa siklus dilakukan dan telah terjadi peningkatan keaktifan mahsiswa, sesuai dengan kriteria yang akan dicapai, maka peneliti dapat mengakhiri penelitian. Selanjutnya pada siklus berikutnya dilaksanakan berdasarkan analisis data hasil observasi, pemaknaan data hasil observasi, penjelasan hasil analisis dan kesimpulan mengenai presentase teratasi atau tidaknya permasalahan dalam pembelajaran, serta faktorfaktor lainnya yang menjadi pertimbangan belum tercapainya target dalam penelitian ini.

Kegiatan perkuliahan dilakukan di dalam kelas serta di luar kelas. Mahasiswa melakukan observasi lapangan ke Sekolah Dasar yeng telah menggunakan pendekatan pembelajaran Tematik, menggali informasi melalui wawancara, diskusi dengan kepala sekolah dan guru serta melakukan pengambilan rekaman berupa video saat pembelajaran berlangsung.

Kegiatan perkuliahan yang berlangsung di dalam kelas melakukan diskusi kelompok untuk membahas data dan informasi yang dihasilkan saat observasi ke Sekolah Dasar kemudian tiap kelompok memepresentasikan hasil observasi masing-masing.

Proses penilaian terhadap keaktifan mahasiswa dilakukan dosen pada saat kegiatan perkuliahan berlangsung baik di dalam kelas maupun di luar kelas.

\section{HASIL PENELITIAN DAN PEMBAHASAN}

Dilihat dari hasil analisis data selama tindakan mulai siklus I sampai siklus II terlihat adanya peningkatan dari semua data yang diambil. Data berupa skor keaktifan mahasiswa melalui pendekatan Scientific mangalami peningkatan, dan hasil analisisnya dapat dilihat pada perkembangan hasil yang dicapai mulai dari siklus I meliputi data hasil observasi yang diperoleh dari lembar observasi tindakan dosen dan mahasiswa.

Hasil pada siklus I pertemuan pertama lembar observasi dosen dengan pendekatan Scientific mencapai $60 \%$ dan kemudian menjadi $100 \%$. Hasil pada siklus I pertemuan 
Pendas : Jurnal Ilmiah Pendidikan Dasar, ISSN Cetak : 2477-2143 ISSN Online : 2548-6950 Volume II Nomor 1, Juni 2017

pertama lembar observasi mahasiswa dengan pendekatan Scientific mencapai $70 \%$ dan kemudian menjadi $100 \%$. Peningkatan ini menunjukkan bahwa pendekatan Scientific yang diterapkan pada proses pembelajaran ini dapat membuat perubahan yang cukup bagi keberhasilan dosen dalam proses pembelajarannya.

Tabel 1. Data Hasil Observasi Keaktifan Mahasiswa Per Siklus

\begin{tabular}{|c|c|c|c|}
\hline \multirow{2}{*}{ Siklus } & \multicolumn{3}{|c|}{ Kategori Nilai Keaktifan } \\
& \multicolumn{3}{|c|}{ Mahasiswa } \\
\cline { 2 - 4 } & Kurang & Cukup & Baik \\
\hline $\begin{array}{c}\text { Pra } \\
\text { Siklus }\end{array}$ & $60 \%$ & $40 \%$ & $0 \%$ \\
\hline I & $0 \%$ & $85 \%$ & $15 \%$ \\
\hline II & $0 \%$ & $30 \%$ & $70 \%$ \\
\hline
\end{tabular}

Hasil observasi terhadap proses perkuliahan pembelajaran tematik sudah memunculkan suasana yang merangsang mahasiswa untuk aktif dengan kenyataan bahwa dari 20 indikator yang diobservasi, 30\% berada pada kategori cukup dan $70 \%$, berada pada kategori baik pada siklus II. Dosen menggunakan pendekatan scientific yang menarik mahasiswa untuk aktif melakukan eksplorasi terhadap pengetahuan, informasi maupun konsep-konsep yang sedang dipelajari

dalam

perkuliahan

pembelajaran tematik, khususnya dalam memecahkan masalahmasalah yang disajikan dalam perkuliahan.

Pada siklus I mahasiswa perkelompok melakukan observasi ke Sekolah Dasar yang telah menggunakan pendekatan tematik. Pada tahap mencari informasi setelah observasi, mereka ditugaskan melakukan wawancara kepada kepala sekolah, kepada guru dan kepada siswa mengenai pendekatan tematik. Setiap anggota kelompok mendapatkan bagian tugas wawancara masing-masing sehingga semua aktif berkerja Data dan informasi juga diambil melalu catatan dokumen yang berkaitan dengan pelaksanaan pendekatan tematik di sekolah.Semua data dan informasi yang diperoleh diolah dalam kerja kelompok kemudian dipresentasikan di dalam kelas.

Pada siklus II perkuliahan diawali dengan kegatan observasi terhadap proses pembelajaran yang menggunakan pendekatan saintik di Sekolah Dasar. Satu kelompok berjumlah 6 orang melakukan pengamatan kegiatan proses pembelajaran yang menggunakan 
Pendas : Jurnal IImiah Pendidikan Dasar, ISSN Cetak : 2477-2143 ISSN Online : 2548-6950 Volume II Nomor 1, Juni 2017

pendekatan tematik pada satu Sekolah, satu kelas dibagi menjadi 5 kelompok jadi ada lima sekolah yang diobservasi, selain melakukan observasi, mahasiswa juga ditugaskan mengambil dokumen berupa video pembelajaran. Mahasiswa melakukan diskusi kelompaok, melakukan analisis dan pembahasan apakah proses pembelajaran yang sudah diamati sudah sesuai denga kaidah-kaidah dan prinsip pembelajaran tematik. Hasil observasi dan diskusi kelompok dipresentasikan per kelompok di depan kelas. Proses perkuliahan yang menarik dengan desain pembagian tugas yang jelas, membuat

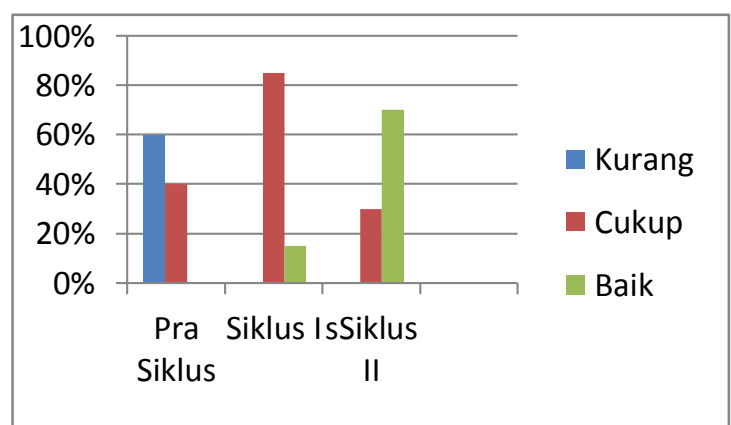

Grafik 1 : Grafik Data Hasil Observasi Keaktifan Mahasiswa Per Siklus

Dari grafik di atas nampak bahwa proses perkuliahan pembelajaran tematik memunculkan suasana yang akan merangsang mahasiswa untuk aktif dengan kenyataan bahwa pada siklus I dan II tidak ada mahasiswa yang keaktifannya berada pada kategori kurang.. Hal ini disebabkan karena penggunaan pendekatan scientific membuat mahasiswa tertarik dengan pembelajaran yang dilakukan di dalam kelas maupun di lar kelas.

\section{DAFTAR PUSTAKA}

BSNP (2008). Makalah Pembelajaran

Tematik. Jakarta : Kemendiknas

Budiningsih, Asri. (2005).Belajar dan pembelajaran. Jakarta: Rineka Cipta.

Daryanto. (2014). Pendekatan Pembelajaran Saintifik Kurikulum 2013. Yogyakarta: Gava Media.

Depdiknas (2006). Model

Pembelajaran Tematik Kelas Awal Sekolah Dasar, Pusat kurikulum Badan Penelitian dan Pengembangan, Departemen Pendidikan Nasional, Jakarta.

Hosnan, M (2014) Pendekatan

Saintific dan kontekstual dalam Pembelajaran abad 21. Bogor: Ghalia.

Martin Cápay and Martin Magdin (2013)“Tasks for Teaching Scientific Approach Using the Black Box Method", Department of Informatics, Faculty of Natural 
Sciences, Constantine the

Philosopher University in Nitra,

Slovaki.

Molenda, dkk., (1996) Instructional

Media and Technologies for Learning, (New Jersey: PrenticeHall, Inc.

Moore,Kenneth .D. Effective Instructional Strategies From Theory and practice (London:Sage Publication)th 2005.

Mulyasa, (2014) Guru dalam Implementasi Kurikulum 2013, ( Bandung : Remaja Rosdakarya.

Sani, R.A.(2013) Pembelajaran Scientific Untuk Implementasi Kurikulum Jakarta: Bumi Aksara.

Syarifudin,H.E. (2010) Strategi Belajar Mengajar, Jakarta: Diadit Media

Zakiah Wulansari, (2015) Implementasi Pendekatan IImiah (Scientific Approach) dan Penilaian Otentik (Authentic Assessment) pada Mata Pelajaran Pendidikan Agama Islam dan Budi Pekerti Di Kurikulum 2013,(Salatiga:PPS Sekolah Tinggi Agama Islam

Ormrod, Jeanne Ellis. Edisi Keenam Psikologi Pendidikan, Membantu Siswa Tumbuh dan Berkembang, terjemahan Wahyu Indianti, Eva Septiana dkk. Jakarta: Erlangga. 2008 